\title{
ІМІДЖЕВА КОМПЕТЕНТНІСТЬ МАЙБУТНЬОГО ВЧИТЕЛЯ ПОЧАТКОВОЇ ШКОЛИ ЯК ОСВІТНЬО-ПРОФЕСІЙНА НОВАЦІЯ
}

Довга Т. Я. Іміджева компетентність майбутнього вчителя початкової школи як освітньо-професійна новація.

У статті здійснено порівняльний аналіз поглядів вітчизняних і зарубіжних науковців на проблему професійної компетентності вчителя. Розкрито сутність іміджевої компетентності вчителя та показано її взаємозв'язок з професійною компетентністю. Подано приклади дидактичних засобів для формування іміджевої компетентності у змісті освітньопрофесійної підготовки майбутнього вчителя початкової школи.

Ключові слова: професійна компетентність, іміджева компетентність, іміджева діяльність, освітньо-професійна підготовка, майбутній учитель початкової школи.

Довга Т. Я. Имиджевая компетентность будущего учителя начальной школы как образовательно-профессиональная новация.

В статье осуществлен сравнительный анализ взглядов отечественных и зарубежных ученых на проблему профессиональной компетентности учителя. Раскрыта сущность имиджевой компетентности учителя и показана ее взаимосвязь с профессиональной компетентностью. Приведены примеры дидактических средств для формирования имиджевой компетентности в содержании образовательно-профессиональной подготовки будущего учителя начальной школы.

Ключевые слова: профессиональная компетентность, имиджевая компетентность, имиджевая деятельность, образовательно-профессиональная подготовка, будущий учитель начальной школы.

Dovga T. Ya. The image competence of future primary school teachers as the educational and professional innovation.

The article presents a comparative analysis of the views of native and foreign scholars on the issue of professional competence of teachers. The essence of teacher's image competence is considered, and its relationship with professional competence is shown. The examples of didactic tools for the formation of image competence in the content of educational and professional training of future primary school teacher have been given.

Key words: professional competence, image competence, image work, educational and professional training, future primary school teachers.

Сучасне українське суспільство потребує оновлення змісту освіти, усвідомлення пріоритету цінностей освіти в системі культурних цінностей особистості, що спонукає науковців до вивчення процесу професійного становлення майбутнього педагога, удосконалення процесу фахової підготовки у вищих навчальних закладах, визначення професійно необхідних якостей сучасного спеціаліста.

Представники психолого-педагогічної науки аналізують процес професійного становлення з різних позицій, а саме: розвитку в майбутнього педагога особистісних та професійно значущих якостей, здібностей та вмінь, сутності різних аспектів педагогічної 
діяльності, результативності професійної підготовки, зокрема формування професійної компетентності.

До вивчення проблеми професійної компетентності в різний час зверталися російські вчені: Е. Зеєр, І. Зимня, А. Маркова, Н. Кузьміна, Л. Мітіна. А. Хуторськой та ін. Вітчизняні дослідники (Н. Бібік, Я. Кодлюк, М. Митник, О. Овчарук, О. Онаць, О. Савченко, І. Соколова, О. Ситник та ін.) активно займаються вивченням професійної компетентності педагогів різного фаху.

Переважна більшість дослідників професійної компетентності за основу їі сутності обирають професійні знання та вміння й визначають зміст означеного поняття: «сукупність професійних знань, умінь, а також способи виконання професійної діяльності» (Е. Зеєр); «сукупність умінь педагога - суб'єкта педагогічного впливу, його особливим чином структуроване наукове і практичне знання задля найкращого розв'язання педагогічних завдань» (Н. Кузьміна); «співвідношення професійних знань і вмінь, $з$ одного боку, i професійних позицій, психологічних якостей - 3 іншої «(А. Маркова); «знання, вміння, навички. а також способи і прийоми їхньої реалізації в діяльності, спілкуванні й розвитку (саморозвитку) особистості» (Л. Мітіна) тощо.

Уважаємо, що реалізація компетентнісного підходу до освіти ставить науковців перед необхідністю більш глибокого проникнення в структуру даного феномену та подальшого пошуку невиявлених або малодосліджених аспектів професійної компетентності.

Метою статті є визначення сутності іміджевого складника професійної компетентності майбутнього вчителя початкової школи та пошук можливостей для іiі формування в змісті освітньо-професійної підготовки.

Під професійною компетентністю прийнято розуміти інтегральну характеристику ділових і особистісних якостей фахівців, яка відображатиме рівень знань, умінь і навичок, досвіду, достатніх для здійснення певного роду діяльності, пов'язаної з прийняттям рішень.

Відповідно до сучасних словникових тлумачень професійна компетентність учителя передбачає володіння необхідною сукупністю знань, умінь і навичок, що визначають сформованість його педагогічної діяльності, педагогічного спілкування й особистості вчителя як носія певних цінностей, ідеалів і педагогічної свідомості; сукупність знань, досвіду, умінь гнучкого володіння педагогічною технологією, віднайдення оптимальних засобів впливу на учня з урахуванням його потреб та інтересів, прав і вільного вибору способів діяльності та поведінки [4, с. 133].

За визначенням С.Дружилова, професійна компетентність педагога $є$ якісною характеристикою особистості фахівця, яка включає систему науково-теоретичних знань як у предметній галузі, так і в галузі педагогіки і психології. Професійна компетентність педагога - це багатофакторне явище, яке включає в себе систему теоретичних знань учителя і способів їх застосування в конкретних педагогічних ситуаціях, ціннісні орієнтації педагога, а також інтегративні показники його культури (мовлення, стиль стосунків, ставлення до себе і своєї діяльності, до суміжних галузей знань тощо. [3, с. 42].

Отже, дослідники професійної компетентності вважають іiі складним, динамічним явищем, яке містить індивідуально вироблені стратегії, засоби орієнтації в дійсності та підходи щодо розв’язання завдань і виокремлюють у їі структурі такі компоненти:

- компетентність діяльності, спілкування та саморозвитку особистості фахівця як основу всісї інтегральної компетентності;

- професійну творчість діяльності, що включає спрямованість на системний пошук засобів та прийомів розв'язання проблем професійної діяльності; 
- системне та модельне мислення як необхідну умову організації та здійснення управлінської праці при розв'язанні складних нестандартних завдань;

- конкретно-предметні знання, що $е$ підгрунтям формування компетентності; праксеологічну, рефлексивну та інформаційну озброєність при розв'язанні різних проблем професійної діяльності тощо.

У науковій літературі останніх років уживаються інваріанти терміна професійна компетентність, такі, як: педагогічна, психологічна, соціальна, комунікативна, екологічна, управлінська тощо. Наведемо деякі з них.

Спеціальна компетентність - володіння власне професійною діяльністю на досить високому рівні, здатність проектувати свій подальший професійний розвиток;

соиіальна компетентність - володіння спільною (груповою, кооперативною) професійною діяльністю, співпраця, а також прийнятими в даній професії прийомами професійного спілкування, соціальна відповідальність за результати своєї професійної діяльності;

аутокомпетентність - адекватне уявлення про свої соціально-професійні характеристики й володіння технологіями подолання професійних деструкцій;

екстремальна професійна компетентність - здатність діяти в умовах, що раптово ускладнилися, під час аварій, порушеннях технологічних процесів.

Болгарська дослідниця Гінка Димитрова розглядає професійну компетентність як інтегральну характеристику конкурентоспроможної особистості та виокремлює в їі складі такі підкомпетентності: концептуальну, комунікативну, конфліктну, компетентність в емоційній сфері, компетентність в окремих сферах діяльності тощо [1, с. 234].

Така структурно-видова різноманітність професійної компетентності відкриває перед науковцями можливості для подальшого розвитку та розгалуження цього складного педагогічного феномену.

Ми погоджуємося 3 думкою М. Митника, що головною метою підготовки фахівця в соціально-економічних умовах суспільства стає не здобуття ним кваліфікації в обраній вузькоспеціальній сфері, а набуття та розвиток певних компетентностей (або компетенцій), які мають забезпечити йому можливість адаптуватися в умовах динамічного розвитку сучасного світу. Це потребує впровадження відповідних змін у зміст професійної підготовки майбутніх фахівців i, у першу чергу, майбутніх педагогів [5, с. 39].

Тому вважаємо необхідним наукове вивчення іміджевої компетентності та спробуємо представити іï як новацію у змісті освітньо-професійної підготовки майбутнього вчителя початкової школи.

Визначення іміджевої компетентності вперше зафіксовано в працях російської дослідниці О. Перелігиної (2003р.), яка вивчала імідж як психологічний феномен: «С особлива комплексна якість суб'єкта іміджу, яка визначається як іміджева компетентність, що являє собою здатність і готовність до створення продуктивного іміджу та його цілеспрямованої корекції в ході інтерсуб'єктної іміджевої взаємодії, спрямованої на оптимізацію іміджу. Іміджева компетентність припускає можливість цілеспрямованого розвитку, ступінь якого співвідноситься з рівнем професіоналізму діяльності зі створення іміджу» [6].

Пізніше це визначення взяла за основу російська дослідниця С. Яндарова (2005р.), яка розглядала іміджеву компетентність як різновид комунікативної компетентності, що забезпечує високий рівень адекватності сприйняття суб'єктами один одного під час іміджевої взаємодії [7]. 
Обидві дослідниці пов'язують іміджеву компетентність з діяльністю зі створення іміджу, тобто іміджевою діяльністю, яку ми розглядаємо як різновид професійної діяльності і вважаємо, що до неї потрібно обов'язково готувати майбутнього вчителя початкової школи.

Іміджева діяльність учителя - різновид професійно-педагогічної діяльності, яка реалізується засобами особистісно-професійного іміджу. Залежно від об'єкта іміджевого впливу ця діяльність поділяється на внутрішню (іміджотворчу) і зовнішню (іміджоперетворювальну):

1. Іміджотворча діяльність - це рефлексивно-творча діяльність учителя, спрямована на самого себе. Вона передбачає цілеспрямоване використання особистісно-професійного іміджу задля особистісного самозростання та професійного самовдосконалення. Під впливом іміджотворчої діяльності відбувається інтенсивний розвиток особистісних та професійно значущих іміджевих характеристик учителя, утверджується його іміджева позиція в педагогічному процесі.

2. Іміджоперетворювальна діяльність - організаційно-творча діяльність педагога, спрямована на учнівську аудиторію (аудиторію іміджу) та шкільне середовище. Використання особистісно-професійного іміджу з такою метою забезпечує вдосконалення іміджевої поведінки вчителя та гуманізацію освітнього середовища. Інструментами (засобами) іміджоперетворювальної діяльності вчителя $\epsilon$ іміджевий вплив та іміджева взаємодія, унаслідок яких у школярів формуються позитивні іміджеві якості, підвищується рівень навчальних досягнень та вихованості.

Суб'єктом іміджоперетворювальної діяльності виступає педагог (iї ініціатор та організатор). Об'єктом зазначеної діяльності є учнівська аудиторія (свідомість, воля, почуття учнів), а предметом виступають іміджеві характеристики школярів, які формуються під дією особистісно-професійного іміджу вчителя в навчально-виховному процесі.

Ефективним засобом формування іміджевої компетентності майбутнього вчителя початкової школи ми вважаємо роботу з педагогічними кейсами під час вивчення ними навчальної дисципліни «Імідж сучасного вчителя»[2]. На першому етапі ми пропонуємо студентам ознайомитися зі змістом педагогічного кейса та відповісти на запропоновані запитання. Наприклад:

\section{«Яким має бути вчитель молодших школярів»}

(Уривок з творів Шалви Амонашвілі)

Перш за все, учитель повинен любити дітей такими, якими вони є. Він повинен однаково ставитися до слухняного малюка й до пустуна, тугодума й кмітливого, старанного й ледачого. Любов і доброта - це основні якості, якими слід керуватися кожному вчителю. Грубе поводження з дітьми неприпустиме. Педагог повинен уміти усвідомлювати учнів, а також шанобливо ставитися до їхніх справ і турбот. Щоб займатися вихованням малюка, під час якого дитина сама є помічником у своєму вихованні, потрібно розуміти іï прагнення, сердечні переживання і душу. Учитель повинен бути оптимістом. Тут йдеться про діяльний оптимізм - педагог якомога глибше проникає в душу малюка, у його внутрішній світ $\mathrm{i}$ віднаходить способи розвитку та виховання. Такі якості, як стриманість, суворість, скромність, щирість, інтелігентність, чуйність, а також любов до життя повинні бути в кожного вчителя (вихователя). Учитель повинен весь час прагнути бути таким, оскільки він $\epsilon$ прямим посередником між малюком і знаннями. Дітлахи вбирають морально-етичні норми, духовні цінності через особистісні риси педагога.

Як ви розумієте поняття «діяльний оптимізм»? Яких рис вимагає від учителя виховання малюків? Виокремте з-поміж них особистісні та професійні якості. 
Другим етапом роботи 3 педагогічним кейсом є самостійна постановка студентами запитань за змістом кейса. На третьому етапі студенти отримують завдання самостійно скласти педагогічний кейс за матеріалами педагогічної спадщини відомих педагогів чи педагогічної періодики та представити його на обговорення в студентській групі.

Робота 3 педагогічними кейсами доповнюється виконанням спеціальних вправ на практичному занятті «Імідж і педагогічна професія».

\section{Вправа «Висловлювання про вчителя»}

Meта: ознайомити студентів з висловами видатних людей про вчителя.

Обладнання: картки з висловами про вчителя.

Інструкція: кожен студент отримує картку, вголос зачитує вислів та пропонує іншим студентам обмінятися думками стосовно почутого.

«Коли вчителі будуть привітні та ласкаві, не будуть відштовхувати від себе дітей своїм суворим поводженням, а будуть приваблювати їх своєю прихильністю, манерами $\mathrm{i}$ словами... Коли вчителі будуть ставитися до учнів з любов’ю, тоді вони легко завоюють їх серце так, що дітям буде приємніше бути в школі, ніж удома» (Я. Коменський).

Учитель, вихователь має бути благочестивим, розумним, сумирно мудрим, лагідним, стриманим, не лиходієм, не злим, не заздрісником, не сміхотворцем, не лихословом, а в усьому показувати зразок для наслідування, і щоб учні були, як їхній учитель (3i статуmу Львівської братської школи 1856 р.).

Я кажу вам: без прагнення до наукової роботи вчитель елементарної школи неминуче підпадає під владу трьох педагогічних демонів: механічності, рутинності, банальності. Він дерев'яніє, кам'яніє, опускається (А. Дістервег).

Тільки рішуча людина, енергійна, з твердим характером, така, що знає, чого вона хоче, чому вона хоче і які засоби ведуть до виконання їі волі, - тільки така людина може виховати рішучих, енергійних, сильних характером людей (А. Дістервег).

Першою і найбільш потрібною учителеві якістю хай буде добронравність. Бо він $є$ дзеркалом, дивлячись в яке, юнаки бачать весь розквіт доброчесті... Отже, хай буде учитель дзеркалом добрих звичаїв, і чого вчить або вчити збирається, те саме, як на зразкові, хай показує на самому собі (О. Духнович).

У школі має бути якнайбільше яскравих барвистих годин. І для того, щоб вихователь захопив дитину розповіддю (а діти дуже люблять розповідь), потрібно бути простим i щирим, самому відчувати й уникати пишних фраз (П. Блонський).

Виховання дітей потребує найсерйознішого тону, найпростішого і щирого. В цих трьох якостях полягає найвища правда вашого життя. Щонайменша брехливість, легковажність прирікають виховну роботу на невдачу (А. Макаренко).

Змушений приховувати i обминати труднощі, вихователь легко може деморалізуватись, стати лицемірним, розчаруватися й розледачити... Виникають скарги на невдячна працю: якщо Бог хоче когось покарати, то робить його вихователем (Януш Корчак).

Учителю потрібно трудитися багато років, щоб побачити предмет свого творіння...; нікого так часто не відвідує почуття невдоволення, як учителя; ні в якій праці помилки й невдачі не призводять до таких важких наслідків, як у вчительській (В. Сухомлинський).

Учителю потрібно володіти величезним талантом людинолюбства i безмежною любов'ю до своєї праці й перш за все до дітей, щоб на довгі роки зберегти бадьорість духу, ясність розуму, свіжість вражень, сприйнятливість почуттів - а без цих важливих якостей праця педагога перетворюється в муку (В. Сухомлинський).

Якщо ви хочете бути улюбленим вчителем, дбайте про те, щоб вихованцеві було, що в 
вас відкривати. Якщо ж ви кілька років однаковий, якщо минулий день нічого не додав до вашого багатства, ви можете стати обридлим і навіть ненависним... Серця й уми юнацтва можна завоювати в наші дні тим сплавом моральної краси та інтелектуального багатства, який відкриває перед юнацтвом все нові й нові якості людини (В. Сухомлинський).

Наведені нами види роботи збагачують педагогічний світогляд студентів та розширюють горизонти їхньої обізнаності зі специфічними рисами професії вчителя, що $\epsilon$ важливим аспектом формування іміджевої компетентності майбутнього вчителя початкової школи.

Отже, іміджева компетентність майбутнього вчителя входить до складу професійної компетентності, а іiі формування $є$ важливою ознакою ефективності освітньо-професійної підготовки та передумовою успішного професійного становлення майбутнього вчителя початкової школи.

\section{Література}

1. Димитрова Г. Формиране на бъдеща конкурентоспособна личност чрез образователно възпитателния процес / Гинка Димитрова // Образование и възпитание за утре - между традицията и иновациите / Фондация «Човещина» «Авангард Прима», 2015. С. 230-243. 2. Довга Т. Я. Імідж сучасного вчителя : [навч.-метод. посіб.] / Т. Я. Довга. - [2ге вид., перероб. і доп.]. - Кіровоград: ПП «Ексклюзив-Систем», 2015. - 146 с. 3. Дружилов С. А. Профессиональная компетентность и профессионализм педагога: психологический подход / С. А. Дружилов // Научно-публицистический альманах : CO PАО, ИПК, Новокузнецк. - 2005. - Вып. 8. - С. 40-49. 4. Коджаспирова Г. М. Словарь по педагогике / Г. М. Коджаспирова, А. Ю. Коджаспиров. - Москва : ИКЦ «МарТ»; Ростов н/Д : Издательский центр «МарТ», 2005. - 448 с. 5. Митник М. М. Професійна компетентність вчителя як загальна умова педагогічної діяльності / М. М. Митник // Професійні компетенції та компетентності вчителя [матеріали регіонального науково-практичного семінару]. Тернопіль : Вид-во ТНПУ ім. В. Гнатюка, 2006. - С. 37-40. 6. Перелыгина Е. Б. Имидж как феномен интерсубъектного взаимодействия: Содержание и пути развития: дисс. ... доктора психол. наук по спец. : 19.00.05, 19.00.13 «Психология развития, акмеология». - Москва, 2003. - 697 с. 7. Яндарова С. В. Имидж личности: содержание, функции и мотивации построения: дисс. ... канд. психол. наук по спец.: 19.00.01 «Общая психология, психология личности, история психологии». - Москва, 2005. - 187 с.

УДК 378.14:37.011.31

Наталия Есина

\section{КОМПЕТЕНТНОСТНЫЙ ПОДХОД В ПРОФЕССИОНАЛЬНОЙ ПОДГОТОВКЕ БУДУЩЕГО ПЕДАГОГА}

Єсіна Н. А. Компетентнісний підхід до професійної підготовки майбутнього педагога.

У статті розкрито поняття «компетентність», «професійна компетентність»; описано види і підвиди професійної компетентності майбутнього педагога, які впливають на результати навчально-виховної та управлінської діяльності студентів; подано авторське визначення «компетенція», визначено структурні складники професійної підготовки майбутнього педагога.

Ключові слова: компетентність, компетенція, професійна компетенція, компетентнісний підхід, підготовка майбутнього педагога, професійна підготовка майбутніх педагогів. 